\title{
Recycling of some selected building materials in the construction industry: Prospect and challenges
}

\author{
Owolabi James $\mathbf{D}^{1}$, Amusan Lekan $\mathbf{M}^{1}$, Udoh Victor ${ }^{1}$, Tunji-Olayeni Patience ${ }^{1}$, Peter Nkolika ${ }^{2}$, \\ Omuh Ignatius $^{1}$, O. Joshua Opeyemi ${ }^{1}$, \\ ${ }^{1}$ Building Technology Department Covenant University, Ogun State Nigeria \\ ${ }^{2}$ Estate Management Department Covenant University, Ogun state Nigeria
}

\author{
Email address: \\ james.owolabi@covenantuniversity.edu.ng (Owolabi J. D), lekan.amusan@covenantuniversity.edu.ng (Amusan L. M) \\ patricia.tunji-olayeni@covenantuniversity.edu.ng (Tunji-Olayeni P.), nkolika.peter@covenantuniversity.edu.ng (Peter N.), \\ ignatius.omuh@covenantuniversity.edu.ng(Omuh I.), opeyemi.joshua@covenantuniversity.edu.ng.s (O. J. Opeyemi)
}

\section{To cite this article:}

Owolabi James D, Amusan Lekan M, Udoh Victor, Tunji-Olayeni Patience, Peter Nkolika, Omuh Ignatius, O. Joshua Opeyemi. Recycling of Some Selected Building Materials in the Construction Industry: Prospect and Challenges. Science Research.

Vol. 2, No. 2, 2014, pp. 21-26. doi: 10.11648/j.sr.20140202.12

\begin{abstract}
The importance of recycling cannot be overemphasized, it decongests items in environment which tends to constitutes pollution nuisance while providing opportunity for reuse of such items, also items recycling returns environment to the state of its naturalness. It is against this background that the study attempt at studying recycling of some selected building materials within the context of their benefits, conceptualization, and awareness about concept of recycling and waste generated. Random sampling technique was used to select the respondents sample and research location. Lagos State, Nigeria, was chosen as research location construction companies and landfills within the state and sample procedure would be as stated above. Seventy (70) Structured questionnaire was used to harvest opinion of people on the subject matter. Also, field research was conducted, field research entails taking data from existing landfills in sites of established waste collection organizations, that is, existing organizations that run recycling operation. Mean Item Score and simple percentage were used to process harvested data. In summary It was discovered that the response to the economic effect of recycling where the purchase of product made from recycled material ranked $1^{\text {st }}$ with a 0.862 index, the next was the participation in recycling for the creation of jobs which ranked $2^{\text {nd }}$ with an index of 0.837 , next was their opinion on the construction industries benefits from the recycling industry which ranked $3^{\text {rd }}$ with an index of 0.81 and Participation in recycling for financial reward which was ranked $4^{\text {th }}$ with an index of 0.735 . Also discovered was the quantity of materials wasted on the various sites and even though the quantity was low in most of the cases, it still reiterated the need for recycling of construction and renovation waste. From the above stated finding it is important to state that the study was extremely important as it provides information on the method of recycling all the wasted materials instead of carting them away to landfills. Approach to recycling of waste has been presented in this study, it is a believe that this could serve as an awareness about concept of recycling household and environmental waste.
\end{abstract}

Keywords: Recycling, Awareness, Process, Challenge, Construction

\section{Introduction}

History of recycling is dated to the time if Plato in 400BC. Scarce resources drove people to reuse of consumables. During these periods, resources were scarce, the archaeological studies of ancient waste dumps show less household waste (such as ash, broken tools and pottery) which implies that more waste was being recycled in the absence of new material in those days[1].

According to a scientific release by Wikipedia and [2], It was estimated that 4.6 billion tons of non-hazardous solid waste materials are produced annually in the United States alone, because of limited study in the area of waste reduction no thorough research has been carried out in this field to determine the estimated quantity of waste generated from the construction and renovation of building in Nigeria. The potential for use of recycled materials in the construction of highways and roads suggests that there are valuable benefits in terms of economic and environmental gains.

Although several states have recycling plans dedicated to such 
ventures, Lagos state does not currently possess a tool to bring expertise from personnel in state and local highway agencies, construction contractors, and consultants into one location to assess non-hazardous materials for recycling and use[3], [4].

In pre-industrial times, there is evidence of scrap bronze and other metals being collected in Europe and melted down for perpetual reuse. In Britain dust and ash from wood and coal fires was collected by 'dustmen' and down cycled as a base material used in brick making. The main driver for these types of recycling was the economic advantage of obtaining recycled feedstock instead of acquiring virgin material, as well as a lack of public waste removal in densely populated areas. In 1813, Benjamin Law developed the process of turning rags into 'shoddy' and 'mungo' wool in Batley, Yorkshire. This material combined recycled fibres with virgin wool. The West Yorkshire shoddy industry in towns such as Batley and Dewsbury, lasted from the early 19 th century to at least 1914 [5].

Industrialization spurred demand for affordable materials; aside from rags, ferrous scrap metals were coveted as they were cheaper to acquire than was virgin ore. Railroads both purchased and sold scrap metal in the 19th century, and the growing steel and automobile industries purchased scrap in the early 20th century. Many secondary goods were collected, processed, and sold by peddlers who combed dumps, city streets, and went door to door looking for discarded machinery, pots, pans, and other sources of metal. By World War I, thousands of such peddlers roamed the streets of American cities, taking advantage of market forces to recycle post-consumer materials back into industrial production.

Beverage bottles were recycled with a refundable deposit at some drink manufacturers in Great Britain and Ireland around 1800, notably Schweppes. An official recycling system with refundable deposits was established in Sweden for bottles in 1884 and aluminum beverage cans in 1982, by law, leading to a recycling rate for beverage containers of $84-99 \%$ depending on type, and average use of a glass bottle is over 20 refills[6].

According to a study carried out by [7] and [8] materials from the construction industry have been recycled over the years, Recycling of demolition waste was first carried out after the Second World War in Germany to tackle the problem of disposing large amounts of demolition waste caused by the war and simultaneously generate raw material for reconstruction. Finally, from the foregoing, the importance of recycling cannot be overemphasized; it decongests the environment of nuisance items that constitutes pollution while providing opportunity for reuse of items. It is against this background that the study attempt at studying recycling of some selected building materials within the context of their benefits, conceptualization, and awareness about recycling and waste generated.

\section{Research Methodology}

The following methods were employed in collecting the information of the project: Research into past practices in the industry, systematic study of previous works, and field survey with the aid of structured questionnaire.

Population: Lagos State, Nigeria, was chosen as research location, construction companies and landfills within the state and sample procedure were used. Seventy (70) structured questionnaire was used to harvest opinion of people on the subject matter.

Field research: Field research entails include taking data from existing landfills in Lagos. Sites of established waste collection organizations were used, that is, existing organizations that run recycling operation.

Simple percentages was used to represented frequencies of some details of the respondents, Mean Item Score with the aid of an Agreement index was used to process respondents responses on the following: Recycling accruals, benefits of recycling Construction materials could be recycled, some of the construction materials recycled in Nigeria presented in this study includes: concrete, roofing non asphalt shingles, wood, gypsum wall board, metals, brick.

New asphalt, according to [9] could be cruched and recycled into new asphalt. This is sold in the form of asphalt paving, aggregates for new asphalt, hot mixes and sub-base for paved road. Likewise, in a study carried out by [10] it was submitted that Trees and brush can be recycled into tissue paper, wrapping, composite mulch and soil. Reuse timbers, plywood, lumber offcuts can be reused. [11] researched into recycling of wood and Gypsum wall board, unused dry wall can be returned to the supplier, and to the company for recycling. The recycled materials can further be used in cement manufacturing and drywall construction.

In another related study, [12] researched into metal recycling, and state that one of the major materials often classified as waste on site is metal off-cut. This could be found at construction demolition sites. Common metal like steel, aluminium and copper are often found on sites as wastes. Such metal off-cuts are melted down and galvanized into metal products.

[13] studied concrete recycling, it was identified that wet and dry concrete could be recycled into usable forms or as inclusion in concrete products. In the case of reinforced concrete, the Iron component is removed and material screened for size and recycled. According to the study, markets outlets for such recycled products includes general fill, base for road works, aggregated for pavement and drainage media construction.

\subsection{Data, Analysis and Results}

Table 1. Designation of the Respondent

\begin{tabular}{llll}
\hline S/N & Designation & Frequency & Percentage (\%) \\
\hline 1. & Architect & 22 & $27.5 \%$ \\
2. & Builder & 20 & $25 \%$ \\
3. & Engineer & 20 & $25 \%$ \\
4. & Quantity Surveyor & 8 & $10 \%$ \\
5. & Others & Nil & Nil \\
\hline
\end{tabular}

Source: 2013 Survey

Designation of Respondents is presented in Table 1 above. It was discovered that $27,5 \%$ were Architects followed by $25 \%$ which were Builders, followed by $25 \%$ which were 
Engineers, followed by 10\% which were Quantity surveyors every other category was unaccounted for.

Table 2. Knowledge of Material Recycling

\begin{tabular}{lll}
\hline Particulars & Frequency & Percentage\% \\
\hline Very Much & 29 & $36.25 \%$ \\
Much & 30 & $37.5 \%$ \\
Not Much & 10 & $12.5 \%$ \\
Very low & 11 & $13.75 \%$ \\
\hline
\end{tabular}

Source: 2013 Survey

As represented in Table 2 the table illustrates in percentage the knowledge base of the respondent on the subject of recycling it is observed that the largest response is the option B that is 'much', while the least represented was the option 'not much'.

Table 3. Financial Benefits of Material Recycling

\begin{tabular}{lll}
\hline Particulars & Frequency & Percentage\% \\
\hline Very Much & 22 & $27.5 \%$ \\
Much & 30 & $37.5 \%$ \\
Not Much & 13 & $16.25 \%$ \\
Very low & 15 & $18.75 \%$ \\
\hline
\end{tabular}

Source: 2013 Survey

Table 3 illustrates in percentages the knowledge base of the respondent on the financial benefits of recycling it is observed that the largest response is the option B that is 'much', while the least represented was the option $\mathrm{C}$ which was 'not much'

Table 4. Conceptualization of Material Recycling

\begin{tabular}{lll}
\hline Particulars & Frequency & Percentage\% \\
\hline Very Much & 15 & $18.75 \%$ \\
Much & 25 & $31.25 \%$ \\
Not Much & 10 & $12.5 \%$ \\
Very low & 30 & $37.5 \%$ \\
\hline
\end{tabular}

Source: 2013 Survey

Table 4 presents percentages of the respondents that favors the concept of recycling it is observed that the largest response is the option D which is 'very low', while the least represented was the option 'not much'.

The Table 4 above shows the response of the respondent as regards their awareness on the subject of recycling as seen in ascending order from options $\mathrm{A}$ to $\mathrm{D}$, the highest response is 'very low' which reaffirms the importance of this study and the need for awareness.

Table 5. Awareness about Material Recycling

\begin{tabular}{lll}
\hline Particulars & Frequency & Percentage\% \\
\hline Very Much & 3 & $3.75 \%$ \\
Much & 7 & $8.75 \%$ \\
Not Much & 27 & $33.75 \%$ \\
Very low & 43 & $53.75 \%$ \\
\hline
\end{tabular}

Source: 2013 Survey
Table 6. Waste Generated for Recycling

\begin{tabular}{lll}
\hline Particulars & Frequency & Percentage\% \\
\hline Very Low & 24 & $30 \%$ \\
Low & 3 & $3.75 \%$ \\
High & 23 & $28.75 \%$ \\
Very High & 30 & $37.5 \%$ \\
\hline
\end{tabular}

Source: 2013 Survey

As represented in Table 5 above, percentages of waste generated in their respective sites was observed. The largest response is the option $\mathrm{C}$ that is 'high', while the least represented was the option B which is 'low' hence emphasizing the need for recycling of the construction and renovation waste.

Table 7. Quantity of Recycled Items Reused

\begin{tabular}{lll}
\hline Particulars & Frequency & Percentage $\%$ \\
\hline Very Low & 58 & $72.5 \%$ \\
Low & 20 & $25 \%$ \\
High & 1 & $1.25 \%$ \\
Very High & 1 & $1.25 \%$ \\
\hline
\end{tabular}

Source: 2013 Survey

Table 6 presents percentages of the quantity of waste materials reused in different sites. it was observed that the largest response is the option A which is 'very low', while the least represented are the options C and D which is 'low' hence emphasizing the need for recycling of the construction and renovation waste.

Table 8. Quantity Of Wood Wasted.

\begin{tabular}{lll}
\hline Particulars & Frequency & Percentage\% \\
\hline Very Low & 20 & $25 \%$ \\
Low & 22 & $27.5 \%$ \\
High & 18 & $22.5 \%$ \\
Very High & 20 & $25 \%$ \\
\hline
\end{tabular}

Source: 2013 Survey

Percentage of quantity of wood wasted on selected site was presented in Table 7, it was discovered that, the largest response is the option B that is 'low', while the least represented was the option $\mathrm{C}$ which is 'high' which shows optimization in the use of the wood in their respective sites never the less it also emphasizes the need to recycle the available construction and renovation waste on the site.

Table 9. Quantity Of Concrete Wasted.

\begin{tabular}{lll}
\hline Particulars & Frequency & Percentage $\%$ \\
\hline Very Low & 25 & $31.25 \%$ \\
Low & 30 & $37.5 \%$ \\
High & 15 & $18.75 \%$ \\
Very High & 10 & $12.5 \%$ \\
\hline
\end{tabular}

Source: 2013 Survey 
Table 8 illustrates Quantity of concrete wasted on sites, it was observed that the largest response is the option $\mathrm{B}$ that is 'low', while the least represented was the option D which is 'very high' hence emphasizing the need for the recycling of construction and renovation waste.

Table10. Quantity Of Plastic Waste Generated on Sampled Sites

\begin{tabular}{lll}
\hline Particulars & Frequency & Percentage\% \\
\hline Very Low & 57 & $71.25 \%$ \\
Low & 10 & $12.5 \%$ \\
High & 12 & $15 \%$ \\
Very High & 1 & $1.25 \%$ \\
\hline
\end{tabular}

Source: 2013 Survey

Table 9 presents quantity of plastic waste generated. It was discovered that the largest response is the option A which is 'very low', while the least represented was the option D which is 'very high' from the results presented here plastic waste constitutes a smaller amount within the population of the study, however the quantity reclaimed should be recycled.

Table 11. Quantity of Glass Wasted on Sampled Sites

\begin{tabular}{lll}
\hline Particulars & Frequency & Percentage\% \\
\hline Very Low & 60 & $75 \%$ \\
Low & 10 & $12.5 \%$ \\
High & 7 & $8.75 \%$ \\
Very High & 3 & $3.75 \%$ \\
\hline
\end{tabular}

Source: 2013 Survey

Quantity of Glass waste generated is scheduled in Table 10 , the largest response is the option A which is 'very low', while the least represented was the option D which is 'very high' from the results presented here glass waste constitutes a smaller amount within the population of the study, however the quantity reclaimed should be recycled.

Table 12. Quantity Of Metal Reinforcement Wasted on Selected Sites.

\begin{tabular}{lll}
\hline Particulars & Frequency & Percentage\% \\
\hline Very Low & 51 & $63.75 \%$ \\
Low & 10 & $12.5 \%$ \\
High & 14 & $17.5 \%$ \\
Very High & 5 & $6.25 \%$ \\
\hline
\end{tabular}

Source: 2013 Survey

Table 11 illustrates quantity of metal reinforcement wasted it presents percentages of the quantity of metal reinforcements waste generated in their respective sites. It was observed that the largest response is the option A which is 'very low', while the least represented was the option D which is 'very high' from the results presented here metal reinforcement waste constitutes a smaller amount within the population of the study, however the quantity reclaimed should be recycled.

Table 13. Economic Effect of Material Recycling

\begin{tabular}{llll}
\hline S/N & Question & Index & Rank \\
\hline 1 & $\begin{array}{l}\text { Purchase of product made from recycled } \\
\text { material. }\end{array}$ & 0.862 & $1^{\text {st }}$ \\
2 & $\begin{array}{l}\text { Participation in recycling for the } \\
\text { creation of jobs. }\end{array}$ & 0.837 & $2^{\text {nd }}$ \\
3 & $\begin{array}{l}\text { Construction industry benefits from the } \\
\text { recycling industry. }\end{array}$ & 0.810 & $3^{\text {rd }}$ \\
4 & $\begin{array}{l}\text { Participation in recycling for financial } \\
\text { reward. }\end{array}$ & 0.735 & $4^{\text {th }}$ \\
\hline
\end{tabular}

The above stated table illustrates the respondents response to the economic effect of recycling where the purchase of product made from recycled material ranked 1 st with a 0.862 index, the next was the participation in recycling for the creation of jobs which ranked 2nd with an index of 0.837 , next was their opinion on the construction industries benefits from the recycling industry which ranked 3rd with an index of 0.81 and Participation in recycling for financial reward which was ranked $4^{\text {th }}$ with an index of 0.735 .

\section{Conclusion and Recommendations}

\subsection{Introduction}

This study researched the recycling of some selected materials in the construction industry, however this section seeks to provide information on the summary of findings, the recommendations, the conclusion the challenges faced and the need for further studies into the subject matter.

\section{Summary of the Findings}

In summary It was discovered that the response to the economic effect of recycling where the purchase of product made from recycled material ranked 1 st with a 0.862 index, the next was the participation in recycling for the creation of jobs which ranked 2nd with an index of 0.837 , next was their opinion on the construction industries benefits from the recycling industry which ranked 3rd with an index of 0.81 and Participation in recycling for financial reward which was ranked 4th with an index of 0.735 . Also discovered was the quantity of materials wasted on the various sites and even though the quantity was low in most of the cases, it still reiterated the need for recycling of construction and renovation waste. From the above stated finding it is important to state that the study was extremely important as it provides information on the method of recycling all the wasted materials instead of carting them away to landfills. 
Table 14. Recycling Accruals

\begin{tabular}{|c|c|c|c|}
\hline $\mathbf{S} / \mathbf{N}$ & Recycling Accruals & Index & Rank \\
\hline \multirow[t]{8}{*}{1} & Recycling Reduces Green House Gas Pollution & 0.88 & $1^{\text {st }}$ \\
\hline & Reduces Convertible Space for Landfill & 0.87 & $2^{\text {nd }}$ \\
\hline & Energy Conservation & 0.86 & $3^{\text {rd }}$ \\
\hline & Environmental Pollution Reduction & 0.82 & $4^{\text {th }}$ \\
\hline & Generates Employment Opportunity & 0.80 & $5^{\text {th }}$ \\
\hline & Reduces Project Disposal Cost & 0.76 & $6^{\text {th }}$ \\
\hline & Reduces Transportation Cost & 0.75 & $7^{\text {th }}$ \\
\hline & Eliminates Cost of Alternative Materials & 0.71 & $8^{\text {th }}$ \\
\hline
\end{tabular}

Table 15. Challenges in Material Recycling

\begin{tabular}{|c|c|c|c|c|c|}
\hline $\mathbf{S} / \mathbf{N}$ & Challenges in Materials Recycling & Builder & Architect & Quantity Surveyor & Engineer \\
\hline 1 & Government Policy & 0.88 & 0.87 & 0.82 & 0.81 \\
\hline 2 & Activity of Trade Union & 0.87 & 0.87 & 0.86 & 0.73 \\
\hline 3 & Transportation & 0.86 & 0.85 & 0.84 & 0.85 \\
\hline 4 & Lack of Adequate Technology & 0.82 & 0.82 & 0.82 & 0.81 \\
\hline 5 & Capital Inaccessibility & 0.80 & 0.80 & 0.81 & 0.81 \\
\hline 6 & Processing Technology & 0.76 & 0.77 & 0.78 & 0.79 \\
\hline 7 & Availability of Scrap Materials & 0.75 & 0.76 & 0.75 & 0.75 \\
\hline 8 & Lack of Adequate Knowledge & 0.71 & 0.71 & 0.72 & 0.73 \\
\hline
\end{tabular}

Some of the challenges often encountered in recycling business is as presented above. Government policy was rated high with Index of 0.88 by Builders and 0.87 by Architects. Activity of Trade Unions was rated with index 0.86 by both Builder and Architect while Transportation was rated 0.86 and 0.87 by Architect and Builder. The index rating of other professional corroborates this trend. Government policy sometimes is harsh on recycling business, taxes and excise charges need to be paid sometimes before establishing the business which discourages investors. Public waste collectors were the only groups licensed by the authority to operate, this tend to disfavor the private investors. Disturbance from union is also a serious challenge as well as transportation and energy problem.

Table 16. Sources of Fund for Material Recycling Bussiness

\begin{tabular}{llll}
\hline S/N & Sources of Fund & Index & Rank \\
\hline 1 & Cooperative Bank & 0.89 & $1^{\text {st }}$ \\
2 & Development Initiative Fund & 0.88 & $2^{\text {nd }}$ \\
3 & Research Business Fund & 0.87 & $3^{\text {rd }}$ \\
4 & Soft Loan from Credit Banks & 0.85 & $4^{\text {th }}$ \\
5 & Personal Contributions & 0.80 & $5^{\text {th }}$ \\
6 & Communal Ownership & 0.65 & $6^{\text {th }}$ \\
7 & Family Ownership & 0.45 & $7^{\text {th }}$ \\
\hline
\end{tabular}

Some of the sources of financing the recycling business according to the study includes: cooperative bank which was ranked $1^{\text {st }}$, development Initiative fund was ranked $2^{\text {nd }}$, fund from Soft loan through credit banks was ranked $3^{\text {rd }}$. Furthermore, personal contributions was ranked $5^{\text {th }}$, communal ownership was ranked $6^{\text {th }}$ while family ownership was ranked $7^{\text {th }}$. Cooperative bank seemed to be more favored than others like credit banks, may be as a result of low interest rate often charged on lending by cooperative outlets. Also funds comes through development initiatives fund, there are number of such such as SURE-P project, Youth Development Forum among others. Funds are made available on presenting viable recycling business proposal.

\section{Challenges}

The challenges faced during the execution of this project could be characterized trivial compared to the challenges on the road ahead to more effective research on this subject matter, as it incredibly large and need alarming attention to details. For the purpose of this study the following where some of the challenges encountered during this particular study: Late response from respondents as regards filling questionnaires with relevant information, Inadequate awareness about the subject matter as would be expected of a developing nation. Indifference from population of the study as regards the topic. Also dilapidated state of landfills made it difficult to carry out thorough research.

\section{Conclusion}

The set aims and objectives for this paper have been duly justified, it is hoped that the knowledge shared in this paper would create the desired results in the industry as this would aid in the creation of new jobs, and further help the economy of the nation while making the participant very, very rich. In conclusion the project has satisfied its aims and objectives, providing a stepping stone for further research into this field.

\section{Recommendations}

The following would be my recommendations:

i. That the government and private individuals provide the much needed awareness about the subject topic.

ii. That such incentives as tax breaks or reductions be given to individuals or organizations that participate in the recycling of construction and renovation waste.

iii. That other individuals carry put more thorough research into this field

iv. And finally that we imbibe recycling as a culture. 


\section{Appendix}

\begin{tabular}{|c|c|c|c|c|c|c|c|c|}
\hline $\mathbf{S} / \mathbf{N}$ & Question & Strongly Agree & Agree & Strongly Disagree & Disagree & Undecided & Index & Rank \\
\hline 1 & $\begin{array}{l}\text { Purchase of product made } \\
\text { from recycled material. }\end{array}$ & 49 & 20 & 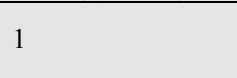 & 7 & 3 & 0.862 & $1 \mathrm{st}$ \\
\hline 2 & $\begin{array}{l}\text { Participation in recycling } \\
\text { for the creation of jobs. }\end{array}$ & 45 & 20 & 0 & 15 & 0 & 0.837 & $2 \mathrm{nd}$ \\
\hline 3 & $\begin{array}{l}\text { Construction industry } \\
\text { benefits from the } \\
\text { recycling industry. }\end{array}$ & 40 & 28 & 0 & 0 & 12 & 0.810 & $3 \mathrm{rd}$ \\
\hline 4 & $\begin{array}{l}\text { Participation in recycling } \\
\text { for financial reward. }\end{array}$ & 40 & 12 & 10 & 8 & 0 & 0.735 & 4th \\
\hline
\end{tabular}

\section{Reference}

[1] Ferguson J, Kermode N, Nash CL, Sketch WAJ, Huxford RP (1995).Managing and minimizing construction waste, A Practical Guide,

[2] Gavilan RM, Bernold LE (1994). Source evaluation of solid waste inbuilding construction, J. Construction Eng. Manag., 120: 536-555.

[3] Waste Management World. (20 June 2013). Recycled Materials Could Supply $90 \%$ of Europe's Construction Needs. June, 20, 2013, http://article-display.articles.waste-management-world.volu me-12.issue-5.regulars.news.recycled-materials-could-suppl y-90-of-europes-construction-needs.QP129867.dcmp=rss.pa ge $=1 . h t m l$

[4] Wahab A.B and Lawal A.F (14 February, 2011). An evaluation of waste control measures in construction industry in Nigeria. June, 11, 2013, http://google.com.ng.recycling.

[5] Ilesanmi O (1986). Materials Management as a Tool for Enhancing Produc tivity on Selected Building Construction Sites in South-Western Part of Nigeria. An Unpublished B.Sc Building Dissertation, Obafemi Awolowo University, Ile-Ife, Nigeria.

[6] Edge environment pty ltd. (17 June 2012). Construction And Demolition Waste Guide - Recycling and Re-Use Across The Supply Chain. June, 12, 2013, http:// google.com.ng/construction and demolition waste recycling.

[7] TIFAC. (11 June 2013). Utilisation of Waste from Construction Industry. June, 11, 2013, http:// tifac.com.index.php.htm

[8] Bossink BAG, Brouwers HJH (1996). Construction waste: quantificationand source evaluation; J. Construction Eng. Manage., 122(1): 55-60.

[9] EPA (2013) Recover Your Resources wwww.arra.org/brownfields/tools/cd brochures.1/5/2014.

[10] Donald T.A and John P.A (2013) Recycling Wood Materials. Journal of Natural and Applied Sciences. 3(2) ,3-9.

[11] Adewole A.M and Ojo S.T (2012) Recycling of Wood and Gypsum Boards. Journal of Environmental Sciences. 4(2). 4-8.

[12] MacDonald S.Q (2012) Recycling of Metal and Metallic Products. Journal of Environmental Sciences. 3(1), 25-38.

[13] Hemmit D. and Simmon H. (2013) Concrete Recycling. European Journal of Sustainable Practice. 3(1). 8-15. 